DOI: https://doi.org/10.18371/fp.1(33).2019.177095

УДК 338.432; 65.011.46

\title{
ФОРМУВАННЯ ЕФЕКТИВНОГО ВИКОРИСТАННЯ ЗЕМЕЛЬНИХ РЕСУРСІВ В ОБЛІКУ, АНАЛІЗІ ТА УПРАВЛІННІ СІЛЬСЬКОГОСПОДАРСЬКИМИ ПІДПРИЕМСТВАМИ
}

\author{
ТКАЛЬ Ярміла Сергївна, \\ к.е.н., дои. кафедри бухгалтерського обліку, \\ Сумський національний аграрний університет \\ ORCID ID: 0000-0002-7646-2266 \\ e-mail: yarmilatkal@ukr.net
}

\author{
АБРАХАМ Юлія Володимирівна \\ к.е.н., дои. кафедри бухгалтерського обліку, \\ Сумський національний аграрний університет \\ ORCID ID: 0000-0002-6178-4078 \\ e-mail:chub-y@ukr.net
}

Анотація: У статті досліджено необхідність інтенсифікації впливу держави на ефективність використання земельних ресурсів. Надмірне використання сільськогосподарських угідь часто є результатом поступового погіршення родючості трунтів. Причинами таких випадків є втрата зернистоі структури трунту, його водопроникність, а також інші впливи на навколишне середовище. Існують випадки деградаиії грунтового покриву внаслідок антропогенного забруднення. Досить велика, а іноді і глобальна небезпека для навколишнього природного середовища обумовлена постійним забрудненням національних чорноземів радіонуклідами, збудниками захворювань. За ичих обставин питання, які потребують негайного дослідження, включають питання збереження земель та раціонального використання з метою забезпечення сталого використання землі в краӥні.

Ключові слова: бухгалтерський облік, діяльність, аналіз, підприємство, основні засоби, земельні ресурси, управління, виробниичтво.
Аннотация: В статье исследована необходимость интенсификации воздействия государства на эффективность использования земельных ресурсов. Чрезмерное использование сельскохозяйственных угодий часто является результатом постепенного ухудшения плодородия почв. Причинами таких случаев потеря зернистой структуры почвы, ее водопроницаемость, а также другие воздействия на окружаюшую среду. Сушествуют случаи деградачии почвенного покрова в результате антропогенного загрязнения. Достаточно велика, а иногда и глобальная опасность для окружающей природной среды обусловлена постоянным загрязнением национальных черноземов радионуклидами, возбудителями заболеваний. В этих обстоятельствах вопросы, требующие немедленного исследования, включающие вопросы сохранения земель и рационального использования с целью обеспечения устойчивого использования земли в стране.

Ключевые слова: бухгалтерский учет, деятельность, анализ, предприятие, основные средства, земельные ресурсы, управление, производство. 
Постановка проблеми. Питання раціонального використання земельних ресурсів сільсько-господарськими підприємствами постійно $є$ актуальним. Адже залучення земельних ресурсів у сільськогосподарський обіг, застаріла матеріально-технічна база, низької якості техніка, недосконалі технології обробітку земельних угідь, недотримання встановлених вимог екології щодо землекористування стали наслідком поширення ерозії, стрімкого зниження родючості грунтів. Діюча система використання земельних ресурсів знаходиться в критичному становищі.

Такі правопорушення, як самовільне захоплення та нецільове використання земельних ділянок, зняття родючого шару без дозволу, забруднення земель, непроведення рекультивації земель завдають значних збитків державі та власникам землі, призводять до незворотної втрати землями якості та родючості. Вчені стверджують, що ефективна протидія порушенням земельного законодавства та недотриманню норм раціонального землекористування $\epsilon$ головною запорукою збереження корисних властивостей землі для майбутніх поколінь, забезпечення високої якості довкілля та умов для проживання людей.

Аналіз останніх досліджень i публікацій. Питання пошуку шляхів удосконалення існуючих технологій раціонального використання земельних ресурсів досліджували у роботах такі учені, як: В.Я. Амбросов, Д.І. Бабміндра, М.С. Богіра, В.Г. В'юн, П.І. Гайдуцький, В.В. Горлачук, О.І. Гуторов, М.Я. Дем'яненко, С.I. Дем'яненко,
Д.С.Добряк, О.С. Дорош, В.Я. МесельВеселяк, Л.Я. Новаковський, П.Т. Саблук, А.Я. Сохнич, А.М. Третяк, М.М.Федоров, Г.В. Черевко, В.В. Юрчишин та ін.

Надмірне використання земельних ресурсів сільськогосподарського призначення часто стає наслідком поступового погіршення родючості грунту. Причинами таких випадків $\epsilon$ втрати грудкувато-зернистої струтури грунту, його водопроникності, а також інші екологічні наслідки. Спостерігаються випадки щодо деградації покриву грунту внаслідок техногенного забруднення. Досить великої, а інколи й глобальної небезпеки природному середовищу завдає постійне забруднення національних чорноземів радіонуклідами, збудниками хвороб. За таких обставин питання, які потребують негайного дослідження, є питання щодо охорони земельних ресурсів та раціонального використання $з$ метою запровадження сталого вітчизняного землекористування.

Мета статті. Метою дослідження $\epsilon$ обгрунтування теоретико-методичних положень та практичних підходів щодо вдосконалення існуючих технологій раціонального використання земельних ресурсів сільськогосподарськими підприємстввами. Теоретико-методологічною базою дослідження стали наукові розробки в галузі управління використанням земельних ресурсів сільськогосподарськими підприємствами.

Виклад основного матеріалу. Еколого-економічний стан сільського господарства визначається двома факторами - природними (клімат, 
метеоумови, антропогенними рельєф) (господарська діяльність людини, машини та механізми, меліорація, агротехніка вирощування сільськогосподарських культур), при дисгармонії яких вони переходять у негативні.

Встановлено, що екологічний стан земель сільськогосподарського призначення, що розглядається «...як вирішальний фактор одержання високоякісної сільськогосподарської сировини, кормів і продуктів, $\epsilon$ незадовільним через інтенсивний характер їх господарського використання i антропогенно-техно- генного навантаження прогресуючою ерозією, підвищеної кислотності, перезволоження, радіаційного забруднення i розвитку інших негативних процесів» [14, с. 46].

Традиційні технології аграрного виробництва спрямовані на збільшення валових зборів i залишають поза увагою якість врожаю та безпеку його подальшого використання. Дослідженнями встановлено, що сільсько-господарському виробництву притаманний високий ступінь екологічних ризиків (рис. 1) [5, c. 423$]$.

\begin{tabular}{|c|c|}
\hline \multicolumn{2}{|c|}{ Екологічні ризики в сільськогосподарському виробництві } \\
\hline Природні & $\begin{array}{l}\text { зумовлені } \quad \text { недоотриманням } \\
\text { продукції внаслідок несприятливокогосподарської }\end{array}$ \\
\hline Антропогенні & $\begin{array}{l}\text { спричинені iндустріалізацією } \quad \text { землеробства } \\
\text { інтенсифікацією механічного обробітку грунтів }\end{array}$ \\
\hline Техногенні & $\begin{array}{l}\text { пов'язані } 3 \text { погіршенням якості грунтів внаслідок } \\
\text { промислового та хімічного забруднення }\end{array}$ \\
\hline Радіаційні & $\begin{array}{l}\text { пов'язані } 3 \text { небезпекою розповсюдження радіоактивних } \\
\text { матеріалів у навколишньому середовищі }\end{array}$ \\
\hline
\end{tabular}

Рис. 1. Екологічні ризики у сільськогосподарському виробництві Джерело: узагальнено авторами за джерелом [5]

Внаслідок проведення земельної реформи склалися умови, котрі змушують негайно вирішити завдання екологічно безпечного та ефективного використання земельних ресурсів. Адже зросла кількість суб'єктів землевикористання, розширилися організаційно-правові форми господдарювання, що у свою чергу перешкоджає здійснити якісний контроль за землевикористанням.
Здавалося б, що передача земель у приватну власність повинна підвищити зацікавленість господаря ефективно iï використовувати. Але навпаки, господарі не мають особливого інтересу додержання всіх принципів екологічних стандартів. Причиною $\epsilon$ складний фінансовий стан сільськогосподарських підприємств, наслідком чого $\epsilon$ 
скорочення витрат на відтворення родючості грунтів.

Справа ще й в тому, що немала частка продуктивних земельних ресурсів передана в оренду. Хоча у договорі офіційно зафіксовані обов'язки орендарів щодо здійснення системи заходів, які стосуються саме охорони земель (захист земель від ерозіі, заростання чагарником, проведення рекультиваціiі), але власник земельного паю не здатний вплинути на стан відтворення грунтів [12, с.111].

Нині важливим та актуальним питанням $\epsilon$ дотримання вітчизняними господарями взятих зобов'язань щодо внесення мінеральних та органічних добрив впродовж терміну використання земельних ресурсів. Відомо, що на формування рівня та якості врожаю сільськогосподарських культур мають як природна родючість грунту, так і кількість, співвідношення та строки використання добрив (перш за все, азоту, фосфору, калію, кальцію, магнію та окремих мікроелементів), засобів захисту рослин, технологія збирання продукції.

Грунт $є$ найважливішою складовою екосистем, а його родючість внаслідок ефективного використання залежить, насамперед, від вмісту i складу гумусу, кількості, надходження i трансформації органічної речовини. Наприклад, на початок 80 -х років XX століття втрати гумусу компенсувалися за рахунок внесення на кожен гектар до 6 т органічних добрив. Однак, на початку XXI століття зменшення норм внесення органічних добрив призвело до збільшення дефіциту гумусу майже уп'ятеро, а щорічні втрати його становлять 600-700 кг/га. Тому найбільш ефективним $\epsilon$ контроль за внесенням добрив під сільськогосподарські культури у сільськогосподарських підприємствах, адже здебільшого господарі-орендарі не передбачають витрати на відновлення родючості грунтів. Досить цікавою причиною $\epsilon$ не намагання землекористувачами максимізувати прибуток, а відсутність джерел фінансування. Підтвердженням такої ситуації $\epsilon$ недостатній, a навіть i досить низький рівень використання сільськогосподарськими

підприємствами мінеральних та органічних добрив (табл. 1).

Сільськогосподарські підприємства Сумської області у 2017 році внесли мінеральні добрива на 93,1 \% посівних площ. Із розрахунку на 1 га посівної площі було внесено 127 кг мінеральних добрив у перерахунку на 100 \% поживної речовини. У загальній динаміці внесення добрив під сільськогосподарські культури у сільськогосподарських підприємствах наявна тенденція до поступового збільшення їх використання.

Хоча мінеральні добрива $\epsilon$ найбільш дієвим та ефективним засобом підвищення урожайності сільськогосподарських культур, але наявну ситуацію не можна вважати задовільною. Адже широке їх застосування призводить до інтенсивної руйнації гумусного шару, a caме зміни його природного мікробіологічного складу та мінералізації, що, у свою чергу, веде до невідновлюваного погіршення якості оброблюваних земель. 
Таблиця 1

Внесення добрив під сільськогосподарські культури у сільськогосподарських підприємствах Сумської області

\begin{tabular}{|c|c|c|c|c|c|c|c|c|c|c|c|}
\hline \multirow[b]{2}{*}{ Показник } & \multicolumn{10}{|c|}{ Роки } & \multirow{2}{*}{$\begin{array}{c}2017 \text { р. до } \\
2000 \text { р., } \\
\%\end{array}$} \\
\hline & 2000 & 2005 & 2010 & 2011 & 2012 & 2013 & 2014 & 2015 & 2016 & 2017 & \\
\hline $\begin{array}{l}\text { Загальна } \\
\text { посівна площа, } \\
\text { тис. га }\end{array}$ & 889,5 & 696,4 & 798,5 & 862,5 & 891,6 & 905,6 & 888,7 & 910,6 & 916,2 & 927,3 & 104,2 \\
\hline \multicolumn{12}{|c|}{ Мінеральні добрива } \\
\hline $\begin{array}{l}\text { Внесено у } \\
\text { поживних } \\
\text { речовинах, тис. } \\
\text { ц }\end{array}$ & 136,1 & 159,1 & 501,9 & 672,9 & 707,5 & 823,2 & 866,4 & 996,9 & 1133,7 & 1177,3 & у 8 раз \\
\hline $\begin{array}{l}\text { Удобрена } \\
\text { площа під } \\
\text { урожай, тис.га }\end{array}$ & 248,6 & 257,5 & 541,7 & 665,2 & 731,7 & 803,9 & 790,6 & 822,2 & 844,5 & 854,2 & у 3 рази \\
\hline $\begin{array}{l}\text { Частка } \\
\text { удобреної } \\
\text { площі, \% }\end{array}$ & 28 & 37 & 68 & 77 & 82 & 89 & 89 & 90 & 92,2 & 93,1 & у 3 рази \\
\hline $\begin{array}{l}\text { Внесено у } \\
\text { поживних } \\
\text { речовинах на } 1 \\
\text { га посівної } \\
\text { площі, кг } \\
\end{array}$ & 15 & 23 & 63 & 78 & 79 & 91 & 97 & 109 & 124 & 127 & у 8 раз \\
\hline $\begin{array}{l}\text { на удобреної } \\
\text { площі, кг }\end{array}$ & 55 & 62 & 93 & 101 & 97 & 102 & 110 & 121 & 134 & 140 & $\begin{array}{l}\text { y } 2,5 \\
\text { рази }\end{array}$ \\
\hline \multicolumn{12}{|c|}{ Органічні добрива } \\
\hline Внесено, тис. т & 1447,6 & 924,3 & 432,7 & 460,6 & 369,0 & 384,5 & 385,4 & 420,8 & 441,1 & 449,2 & 31,0 \\
\hline $\begin{array}{l}\text { Удобрена } \\
\text { площа, тис. га }\end{array}$ & 57,2 & 44,2 & 24,2 & 27,7 & 14,6 & 17,7 & 18,5 & 14,0 & 14,4 & 14,7 & 25,7 \\
\hline $\begin{array}{l}\text { Частка } \\
\text { удобреної } \\
\text { площі, \% }\end{array}$ & 6 & 6 & 3 & 3 & 2 & 2 & 2 & 2 & 1,6 & 1,7 & 28,3 \\
\hline $\begin{array}{l}\text { Внесено на } 1 \text { га } \\
\text { посівної площі, } \\
\text { т }\end{array}$ & 1,6 & 1,3 & 0,5 & 0,5 & 0,4 & 0,4 & 0,4 & 0,5 & 0,5 & 0,5 & 31,3 \\
\hline $\begin{array}{l}\text { удобреної } \\
\text { площі, т }\end{array}$ & 25,3 & 20,9 & 17,8 & 16,5 & 25,2 & 21,7 & 20,8 & 30,1 & 30,7 & 30,9 & 122,1 \\
\hline
\end{tabular}

Джерело: розраховано авторами за джерелом [11].

Проілюструємо вихідні дані у вигляді діаграм для впровадження мінеральних добрив для сільськогосподарських культур (рис. 2) та введення органічних добрив для сільськогосподарських культур (рис.
3) у у сільськогосподарських підприємств Сумської області.

Провідна роль у призупиненні тенденції щодо зниження вмісту гумусу в грунтах, а також поступового досягнення його балансу належить органічним добривам. 
У практиці сільськогосподарського виробництва широко вико ристовуються органічні добрива - такі, як підстилковий гній, гноївка, компости За даними ФАО [10, с. 14], внесення в грунти 1 кг добрив $(\mathrm{N}+\mathrm{P} 2 \mathrm{O} 5+\mathrm{K} 2 \mathrm{O})$ призводить до на основі гною, пташиний послід, середньому на 7,3 кг, рису - на 8,6 кг, вторинна продукція рослинництва, кукурудзи - на 8,8 кг відповідно. сидерати, солома, торф, мул ставків, Оцінка впливу різних факторів на різні органо-мінеральні суміші та урожайність сільськогосподарських інше. культур дало наступні результати:

Система добрив повинна відпо- добрива - 41\%, гербіциди - 15-20\%, відати оптимальному спів від- багатий грунт $-15 \%$, гібридне насіння ношенню поживних елементів із $-8 \%$, зрошення грунтів $-5 \%$, інші врахуванням вимог окремої культури, фактори - 11-16\%. а також наявності в грунті поживних речовин.

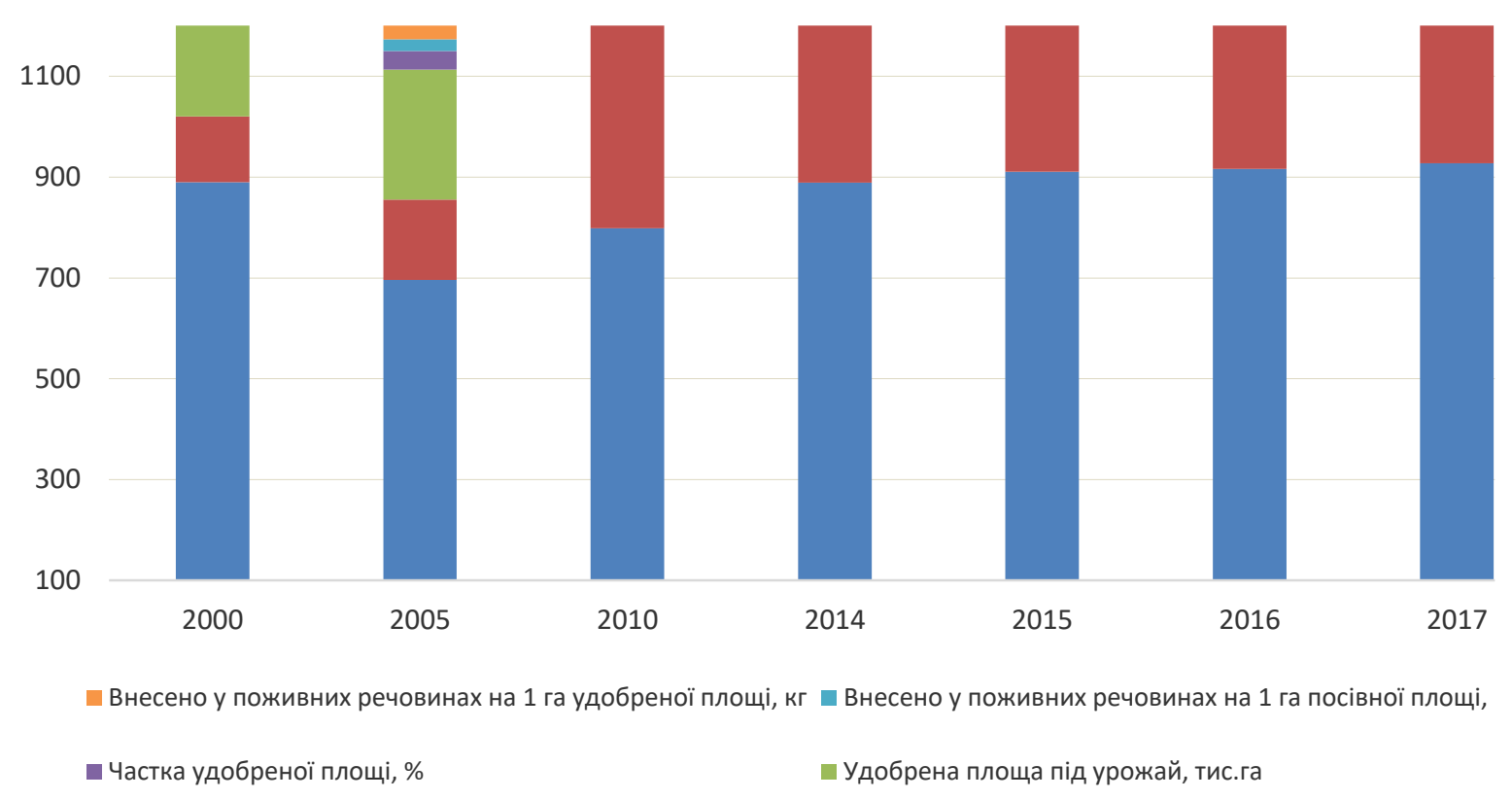

Рис. 2. Внесення мінеральних добрив під сільськогосподарські культури у сільськогосподарських підприємствах Сумської області Джерело: розраховано авторами за джерелом [11]. 


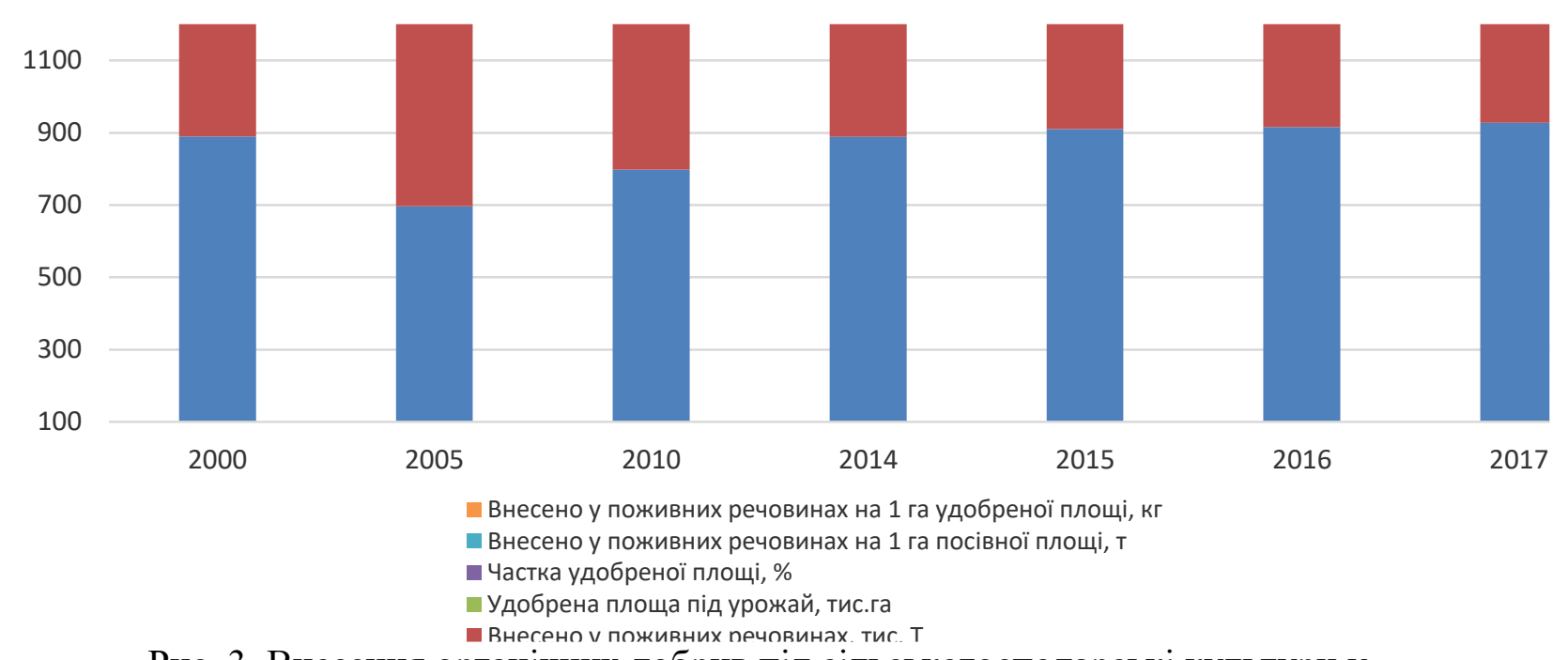

Рис. 3. Внесення органічних добрив під сільськогосподарські культури у сільськогосподарських підприємствах Сумської області Джерело: розраховано авторами за джерелом [11]

На думку В. Мінєєва «...боротьбу за екологічну безпеку треба розглядати як одне 3 най відповідальніших завдань, які стоять перед фахівцями різних галузей народного господарства» [7].

У 2017 році досліджуваними сільськогосподарськими підприємстввами Сумської області близько 69 \% речовини мінеральних добрив, що були ними внесені, припадало на азотні. Як відомо, порушення в технологіях внесення мінеральних добрив, а також їх низька якість можуть стати причиною зниження родючості грунту, внаслідок чого це впливатиме на якість продукції сільськогосподарського виробництва. Досить невтішним у вітчизняних підприємствах $€$ стан внесення органічних добрив, а зокрема лише під $3 \%$ посівних площ у 2017 році вони були внесені. За результатами досліджень, у співвідношенні до 1 га посівних площ основних видів сільськогосподарських культур припадало по 0,5 т органіки. Якщо порівнювати даний показник 3 аналогічним за 1990 рік, він становив 8,8 т, що значно менше, а зокрема на $94,3 \%$. Причина низького використання органічних добрив зменшення поголів'я худоби $\mathrm{y}$ сільськогосподарських підприємствах. У світі органічне сільськогосподарське виробництво набуває все більшої популярності, при цьому спостерігається тенденція до збільшення площ i кількості господарств (ферм) у всіх регіонах (табл. 2).

Одним із шляхів покращення даної ситуації $\epsilon$ вирощування сидератів. Адже за високих врожаїв зеленої маси сидератів у грунт з розрахунку на 1 га надходить азот, фосфор такалій. Переваги вирощування сидеральних культур очевидні (покращення водного режиму грунту, зниження його кислотності тощо), а затрати при цьому невеликі. 
Однак, таким видом добрив дещо складно регулювати вміст гумусу на запланований урожай. Це можна пояснити тим, що сидерати нині вирощують, як всі інші культури, і це пов'язано 3 певним переліком технологічно необхідних робіт (підготовка грунту до посіву, посів, внесення добрив, вартість насіння тощо). Як правило, всю зелену масу цих рослин заорюють, тому що вона $\epsilon$ основним носієм азоту i негуміфікованої речовини. Так, при коефіцієнті гуміфікації 0,15 на 1 га може утворитися в перші два роки 3,6/га гумусу.

Таблиця 2

Розвиток органічного землеробства у деяких країнах світу за 2012-2017 pp.

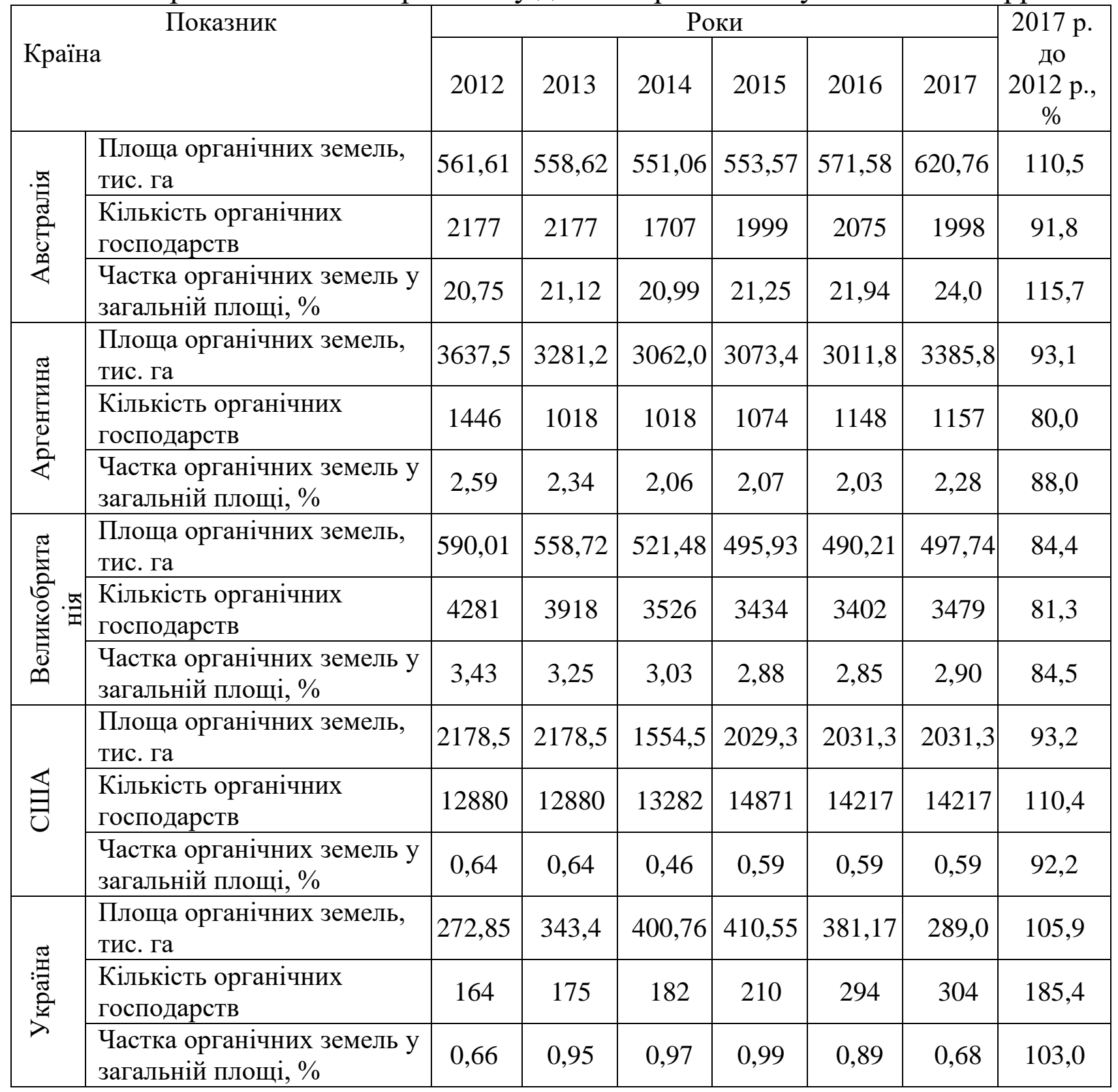

Джерело: розраховано авторами за джерелом [8]. 
Варіант поповнення гумусом грунту за рахунок внесення гною нами розглядається як один із можливих, але не основним у сучасних умовах. Без державної підтримки галузі тваринництва у найближчій перспективі збільшити виробництво гною практично неможливо.

Актуальною використання соломи з органічною речовиною грунту. Адже ця побічна продукція традиційно використовувалася для потреб галузі тваринництва (переважно на підстилку). Деяка частина соломи використовувалася на корм худобі. При цьому значні обсяги заготовленої соломи залишались на полях невикористаними. Нами було досліджено дане питання.

Перш за все, нами було поставлено питання: як та за рахунок чого можливо забезпечити раціональне внесення добрив у грунти, що у свою чергу підвищує ефективність використання земельних ресурсів? Адже зі зростанням цін постійно підвищується вартість мінеральних добрив, що змушує сільськогосподарського товаровиробника менше вносити їх. Нині середня ціна 1 т діючої речовини мінеральних добрив перевищує 9,1 тис. грн., тоді як у 2007 році вона була 3,3 тис. грн.

Тому відповідь наступна: велику кількість мінеральних добрив можна замінити органічними, серед яких провідне місце займає гній.

Виникає обмеження: виробництво даної побічної продукції тваринництва залежить від кількості поголів'я тварин. Але саме ця галузь у більшості вітчизняних підприємств занепадає. Слід шукати інший альтернативний варіант вирішення проблеми. Ми дійшли до наступних тверджень i висновків. Солома також використовується як добрива шляхом внесення безпосередньо органічних решток у грунт після збирання зернових культур. Тому заорювання соломи та пожнивних решток $є$ одним із засобів підтримання родючості грунтів. Але, внаслідок безвідповідального ставлення до охорони земель, здійснюється масове випалювання цього цінного добрива.

Проведені розрахунки ефективності варіанту використання органічних решток подрібненої соломи після збирання врожаю зернових та залишення iї на полі як органічного добрива (табл. 3).

У розрахунку на 1 т соломи визначено ефективність іiі використання при безпосередньому внесенні їі в грунт, що визначалася в еквіваленті до вартості мінеральних добрив.

За результатами наведених розрахунків можна стверджувати, що пропоноване використання, а зокрема внесення 1 т подрібненої соломи безпосередньо в грунт для одержання органічних добрив забезпечує економію коштів у сумі 88,8 грн. та підвищує рівень ефективності виробництва, зокрема зернових культур, на 5 \%, а отже позитивно відбивається на ефективність використання земельних ресурсів, в цілому.

Як було вже зазначено, грунтовий покрив є одним із головних най цінніших природних ресурсів області, 
тому необхідне посилення його ерозійних процесів, забруднення, охорони від негативного впливу інших видів деградації.

Таблиця 3

Ефективність використання органічних решток подрібненої соломи як органічного добрива при безпосередньому внесенні їі в грунт

\begin{tabular}{|l|c|c|}
\hline \multicolumn{1}{|c|}{ Показники } & Одиниці виміру & Результати розрахунків \\
\hline $\begin{array}{l}\text { Собівартість одержуваних із 1 т соломи } \\
\text { поживних речовин }\end{array}$ & грн. & 55,0 \\
\hline $\begin{array}{l}\text { Планується одержати добрив 3 1 т соломи, } \\
\text { всього NPK: }\end{array}$ & & \\
\hline - азоту & кг & 5 \\
\hline - фосфору & кг & 2 \\
\hline - калію & кг & 10 \\
\hline Всього NРК & кг & 17 \\
\hline Ціна 1 кг NРК & грн. & 11,0 \\
\hline Загальна вартість одержаних добрив & грн. & 132 \\
\hline Економія & грн. & 240 (у 2,4 рази) \\
\hline $\begin{array}{l}\text { Рівень ефективності використання соломи } \\
\text { в якості органічного добрива }\end{array}$ & $\%$ & \\
\hline
\end{tabular}

Джерело: розраховано авторами.

В межах Сумської області виділено 70 видів грунтів, які, в свою чергу, за механічним складом та іншими ознаками підрозділяються на 250 грунтових відмін. Причиною такої розмаїтості та строкатості грунтового покриву $\epsilon$, насамперед, наявність на території області двох основних грунтово-кліматичних зон - Поліської, Лісостепової та чітко визначеної між ними Перехідної зони.

В грунтовому покриві Поліської зони переважають дерново-підзолисті грунти легкого механічного складу на водно-льодовикових відкладах (10,2\% обстеженої площі орних земель), а в Лісостеповій - чорноземи типові глибокі малогумусні та їх слабоеродовані відміни (56\%), чорноземи опідзолені на плесових породах та їх слабоеродовані відміни $(22,3 \%)$.

До найбільш родючих грунтів області відносяться чорноземи типові глибокі середньо- та важкосуглинкові з вмістом гумусу 3,5-5,0\% з глибиною гумусного горизонту 100-120 см, які за шкалою бонітету мають оцінку 54 бали. До грунтів 3 низьким рівнем родючості відносяться дерновопідзолисті зв'язнопіщані 3 вмістом гумусу до 1\% та глибиною гумусового горизонту 18-20 см, вони мають оцінку 9 балів.

Середній бал бонітету грунтів області становить 39, середній по Україні - 41. Одним із головних показників родючості грунтів $є$ вміст в них гумусу. За його вмістом землі сільськогосподарських угідь розподіляються на групи, площі яких наведені: до 2\% - 184 тис. га (16 \%); 2$3 \%$ - 215 тис. га (19\%); 3-4\% - 343 тис. га $(30 \%) ; 4-5 \%$ - 345 тис. га (30\%). Таким чином, природні фактори для сільськогосподарського виробництва є помітними. 
Однією 3 причин низьких темпів проведення даного виду робіт $\epsilon$ відсутність фінансування. 3 метою вирішення питання рекультивації земель слід здійснювати асигнування грошових коштів з бюджету держави. Слід зауважити, що власникам паїв потрібно слідкувати за змінами у структурі посівних площ шляхом проведення чіткого контролю щодо виконання всіх обов'язків орендарем, які стосуються збереження родючості використовуваних ним земельних угідь. Скорочення посівних площ, у першу чергу, пов'язане 3 гострою нестачею сільськогосподарської техніки (рис. 4).

Екстенсивне землеробство $\epsilon$ головною причиною ерозії, дефляції, дегуміфікації, перезволоження й інших видів деградації грунтів i ландшафтів. Більшість нових землекористувачів не мають належного досвіду та навиків сільськогосподарської діяльності, а часто й відповідної освіти [8, С. 10].

Наслідками використання недосконалої техніки під час проведення робіт щодо виробництва сільськогосподарських культур можуть бути ущільнення кореневмісного шару грунту, уповільнення росту й розвитку кореневої системи рослин, зниження урожайності на 20$30 \%$, порушення грудкуватозернистої структури грунтів, зниження ïх водопроникності. Саме тому використання сучасної техніки та технологій, котрі забезпечують скорочення чисельності проходів сільгоспмашин полем, a також запобігають погіршенню фізикохімічних властивостей грунтів. Тому сучасні технології виробництва сільськогосподарської продукції мають забезпечувати найповніше використання земельних ресурсів за максимально можливого скорочення витрат антропогенної енергії на одиницю врожаю та зниження негативної дії сільськогосподарських культур на навколишнє середовище.

Давньокитайські землероби придумали такий влучний вислів: «Нездара вирощує бур'яни, розумний отримує врожай, а мудрий плекає землю» [10, c. 19].

Питання забезпечення ефективного використання земельних ресурсів сільськогосподарськими підприємстввами необхідно вирішувати із врахуванням політичних, економічних, а також соціальних складових елементів земельних відносин. Адже у залежності від умов та результатів використання земельних угідь змінюється рівень життя громадян, майбутній достаток суспільства.

У світовій практиці роль держави у питанні ефективного використання земельних ресурсів і підвищення якості земель сільськогосподарського призначення значна. У країнах Європейського Союзу фермер щорічно отримує 242 євро на 1 гектар, але за умови, що ним були дотримані встановлені критерії екологічності використання земельних ресурсів [5, c. 425]. 


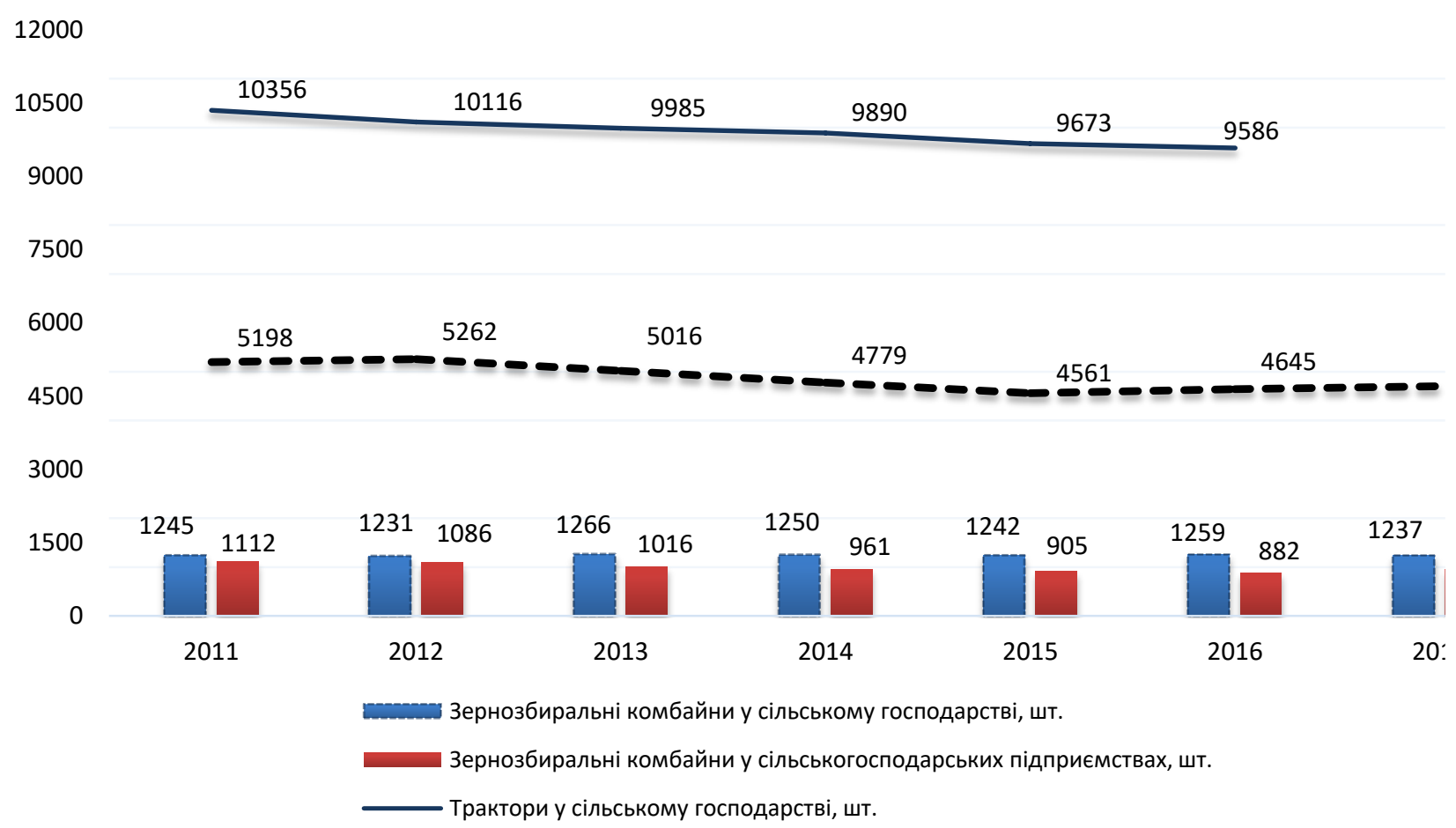

Рис. 4. Динаміка наявності зернозбиральних комбайнів і тракторів усіх марок у сільському господарстві Сумської області

Джерело: розраховано авторами за джерелом [11].

Стан бухгалтерського обліку в забезпечення цінного аграрного сільськогосподарських суб'єктах гос- менеджменту, а саме: незавершеність поддарювання вказує на те, що земельної реформи та відсутність землеустрій у господарствах зводиться до визначення та аналізу динаміки окремих природних показників ефективного використання земель сільськогосподарського призначення, зокрема: урожайності сільськогосподарських культур, коефіцієнтів повернення (окупності) добрив та витрати на поліпшення показників якості сільськогосподарських угідь. На сьогодні система показників витрат, зокрема, ціннісно орієнтованого землеустрою, залишається поза увагою.

Виходячи 3 вищевикладеного, слід виділити основні проблеми, які призводять до суттєвого обмеження бухгалтерського та аналітичного забезпечення повного інформаційного прозорих та зрозумілих механізмів для сільськогосподарських земель значення, що перешкоджає систе-матичній оцінці вартості аграрного бізнесу; низький рівень концепцій та інструментів ціннісного орієнтування серед вищого керівництва аграрних суб'єктів; недосконалість фінансової звітності в Україні в контексті відображення інформації про стан, доступність та оцінку земель сільськогосподарського призначення у звіті про фінансовий стан, що призводить до низького рівня аналітичної роботи в агробізнесі, відсутності фахівців у плануванні, економічній та аналітичній підтримці аграрного управління [3]. 
Оцінка вартості сільськогосподарських земель залишається головною проблемою бухгалтерського та аналітичного забезпечення землеустрою. Створення повноцінного ринку землі сприятиме процвітанню через поліпшення статусу багатства та довгострокових інвестицій. Окрім того, що ринок землі $\epsilon$ передумовою для інвестицій, які сприяють підвищенню продуктивності праці та збільшенню доходів фермерів, зростає інтерес інвесторів до сільськогосподарських земель. На думку вчених, права власності на землю підвищують продуктивність, споживчі витрати та доходи землекористувачів. Основним законом, який формує правову основу в земельних відносинах в Україні, є Конституція України. Стаття 14 Конституції встановлює, що земля $\epsilon$ основним національним багатством, яке перебуває під особливим захистом держави. Власність на землю гарантована. Таким чином, Конституція України закріплює основні конституційні положення щодо землі, які $\epsilon$ основою для галузевого земельного законодавства. Основними нормативно-правовими актами, що регулюють бухгалтерський облік земель, є Положення (стандарти) бухгалтерського обліку, які розробляються Методичною радою 3 бухгалтерського обліку на державному рівні.

Облік, як потужна інформаційна система, може підвищити ефективність управління землею на рівні держави, регіону, громади та підприємства. Вирішення цих проблем може бути забезпечене лише шляхом визнання землі як конкретного активу i об'єкта бухгалтерського обліку, реалізації законодавчих норм i запровадження ефективного обліку та інформаційного забезпечення земельних відносин. Для багатовекторного відображення земельного потенціалу підприємства необхідно здійснювати адекватну реєстрацію земельних ділянок на підприємстві, що важливо для його місії із залучення інвестицій, отримання кредитів тощо.

Згідно 3 нормами (стандартами) бухгалтерського обліку України земля, що належить підприємству, відноситься до основних засобів. Як частина основних засобів українських підприємств, земля з'явилася після набрання чинності Положеннями (Стандартами) бухгалтерського обліку 7 «Основні засоби» та МСБО 16 «Основні засоби», де вона була класифікована на два окремі елементи: землю та капітальні витрати на поліпшення земель [4].

Українське законодавство зробило значний акцент на юридичному закріпленні права власності на землю, однак воно не забезпечило належного обліку використання земель сільськогосподарського призначення. Це, у свою чергу, створило значні проблеми для аграрного бізнесу. Аналізуючи стан правового регулювання обліку сільсько-господарських земель відповідно до українських та міжнародних правових норм, слід розрізняти основні нормативні документи (рис. 5). 


\begin{tabular}{|c|c|}
\hline \multirow{4}{*}{$\begin{array}{l}\text { Особливості } \\
\text { землі як } \\
\text { об'єкта } \\
\text { обліку }\end{array}$} & Об'єктом обліку є не земля взагалі, а деякі ділянки землі \\
\hline & Земельна ділянка є одним із видів основних фондів \\
\hline & $\begin{array}{l}\text { Збільшення початкової вартості земельної ділянки можливе } \\
\text { лише у випадку надлишку }\end{array}$ \\
\hline & $\begin{array}{l}\text { Капітальні витрати на поліпшення землі не збільшують } \\
\text { початкову вартість об'єкта, а визнають як окремий основний } \\
\text { актив }\end{array}$ \\
\hline
\end{tabular}

Рис. 5. Особливості землі як об'єкта обліку

Джерело: узагальнено авторами за джерелом [4].

Базуючись на досвіді розвинених країн, більшість вчених вважають земельну реформу частиною переходу України до цивілізованої ринкової економіки. Це дозволить сформувати прозорий ринок сільськогосподарських земель, що дасть змогу реалізувати конституційні права власників землі та підвищити добробут сільських жителів; зупинити тіньовий рух земель сільськогосподарського призначення i поставити його в правову базу; покращити кредитування та інвестиційний клімат у секторі; для захисту грунтів і цивілізованого землекористування.

Земля $\epsilon$ основним національним багатством, яке перебуває під спеціальним державним захистом. У сільському господарстві земля $\epsilon$ найважливішим економічним ресурсом, що є суттєвим для виробничого процесу. Організація обліку землі на підприємствах повинна враховувати основні особливості землі як об'єкта обліку. Дуже важливим питанням, яке виникає в обліку землі та земельних відносинах, $є$ вдосконалення нормативно-правової бази у сфері бухгалтерського обліку, яка повинна бути чіткою, зрозумілою та доступною, особливо для практикуючих фермерів. Проте ні міжнародні стандарти бухгалтерського обліку та звітності, ні внутрішні стандарти бухгалтерського обліку не мають чіткого законодавчого регулювання земельного рахунку з іншою метою, а також права на їх використання, віднесення їх до балансу підприємств та організацій різної форми власності. Сьогодні існує два шляхи створення ефективної методології бухгалтерського обліку, що дозволить залучити сільськогосподарські землі для економічного обміну та забезпечити покриття пріоритетної капітальної вартості землі підприємств аграрного сектору: поправки до МСФЗ; розвивати власний галузевий стандарт [9].

Незважаючи на те, що в Україні існує мораторій на продаж земель сільськогосподарського призначення, землю, як i будь-який інший економічний актив, слід достовірно оцінити. Оцінка земельної ділянки 
відображається в обліку не тільки для негайного виконання цивільноправових договорів, пов'язаних iз землею в ринковому секторі (купівляпродаж, оренда, успадкування, допуск до капіталу, примусове вилучення), але при розрахунку часу земельного податку , при визначенні загальної вартості майна - будівель на земельній ділянці, у разі формування інвестиційної політики та реструктуризації сільськогосподарських підприємств, якщо економічне обгрунтування ефектив-ного та результативного використання землі, для страхування нерухомості тощо. Саме тому грошова оцінка повинна стати завершальним етапом складних техніко-економічних заходів для оцінки активів підприємства, що дозволить в достатній мірі вірогідно встановити ціну землі певної якості. Розрахункова вартість землі сьогодні визначається встановленим методом оцінки коефіцієнтів функціонального використання земель. Цю оцінку оцінюють фахівці з оцінки земель.

Висновки. Таким чином, реалізація поставлених пріоритетних завдань надасть змогу досягти розвитку ефективного використання земельних ресурсів, а зокрема підвищити їх інвестиційну привабливість; в екологічній площині - забезпечити екологічну безпеку суспільства, в соціальній - підвищити соціальні стандарти життя. Українське законодавство приділяє значну увагу питанням юридичного закріплення права власності на землю, але рівень реєстрації землі в Україні є низьким через недосконалу нормативну базу, що викликає неадекватне відображення господарських операцій у бухгалтерському обліку та зменшує здатність відображати всю інформацію, необхідну для зовнішніх і внутрішніх користувачів. Залежно від способу набуття права власності та використання, доцільно розглядати земельні ресурси в сучасній системі обліку України як: основний актив (майно); нематеріальний актив для прав користування; об'єкт орендних відносин; інвестиційна нерухомість. Щоб підвищити надійність аналітичної власності та інформації на синтетичні рахунки, що використовуються для реєстрації землі, доцільно відкрити додаткові субрахунки другого, третього і четвертого рівнів. Щоб збільшити інвестиційну привабливість земельних ресурсів, необхідно, по-перше, сформувати основні перспективні інвестиційні цілі, які б визначали стратегічні та тактичні дії власників та землекористувачів у залученні інвестицій, а по-друге, побудувати ефективну систему управління сільськогосподарськими підприємствами. Це сприятиме розширенню та процвітанню, а також залученню інвесторів та збільшенню можливостей щодо припливу інвестицій.

Удосконалення інформаційноаналітичного забезпечення розвитку сільського господарства полягає у створенні ефективної системи формування, обробки та передачі (одержання) обліково-аналітичних даних обліку для своєчасного прийняття ефективних рішень на всіх рівнях розвитку аграрного сектору. Конкретним об'єктом бухгалтерського 
обліку є землі сільськогосподарського призначення та земельні відносини, що виникають у процесі його використання. Інформаційна база, яка існує сьогодні, не $є$ цілком досконалою i непрацюючою; не розроблені первинні документи, що відображають особливості обліку земельної ділянки, їх оцінки та подальшого відображення на рахунках. Особливості земель сільськогосподарського призначення вимагають класифікації їх як окремої групи основних засобів i розробки конкретних методів обліку та оцінки активів і прав на їх використання. Для забезпечення цієї вимоги доцільно проводити їх кількісну та якісну оцінку шляхом регулювання бухгалтерського обліку сільськогосподарських земель, запровадження окремого національного галузевого стандарту бухгалтерського обліку.

\section{Список використаної літератури}

1. Богіра М. С. Землекористування в ринкових умовах: еколого-економічний аспект : монографія / за заг. наук. ред. М. С. Богіри. Львів : Львівський національний аграрний університет, 2008. 225 с.

2. Боклаг В. Державний захід щодо удосконалення використання та охорони земель, які посаджені захисним лісом. Балтійський журнал економічних наук, 2016. C. 2-14.

3. Бордюжа А. Удосконалення земельної інформаційної системи сільськогосподарських земель в Україні. Збалансовані природні ресурси, 2014. Вип. 1. С. 151-161.

4. Bryk G. V., Cic'ka N. E., Poverlyak T. I. Theoretical and practical aspects of accounting agricultural land. Economic Processes Management: International Scientific EJournal, 2017. № 1. Retrieved from http://epm.fem.sumdu.edu.ua/download/2017_1/epm2017_1_4.pdf

5. Вороновська О. В. Еколого-економічний аналіз використання земель сільськогосподарського призначення. Землеустрій $і$ кадастр, 2009. Вип. 17 (2). C. 421-426.

6. Гуторов О. І. Земельно-ресурсний потенціал та проблеми його раціонального використання. Харківський наиіональний аграрний ун-т ім. В.В. Докучаєва. Х. : [б.в.], 2002. 69 с.

7. Минеев В. Г. Химизация земледелия и природная середа. М.: Агропромиздат, 1990. $287 \mathrm{c}$. 
8. Willer H., Lernoud J.The World of Organic Agriculture Statistics and Emerging Trends 2019. Retrieved from https://www.organic-world.net/yearbook/yearbook2019/pdf.html

9. Руденко М. В. Формування концепції ризик-менеджменту аграрних підприємств. Вісник Херсонського держсавного університету. Економічні науки. 2017. Вип. 26 (1). С. 171-175.

10. Brukhanskyi R. F., Yazlyuk B., Bincharovska T. A. (2018). Effective land management in Ukraine using accounting and analytical support. Problems and Perspectives in Management, 16(2): 241-251. doi:10.21511/ppm.16(2).2018.22

11. Ситник К., Багнюк В. Стан грунтів і майбутне людства. Вісник НАAН України, 2008. Вип. 8. С. 3-27.

12. Сільське господарство Сумської області. Статистичний збірник, 2017. URL: http://sumy.ukrstat.gov.ua/

13. Трегобчук В. М. Відтворення та ефективне використання ресурсного потенціалу АПК (теоретичні і прикладні аспекти). К.: Ін-т економіки НАН України, 2003. 259 с.

14. Третяк А., Другак В., Осадча І. Стратегія аграрно-земельної політики України в умовах сучасної світової продовольчої кризи. Землевпорядний вісник, 2008. Вип. 5. С. 4-15.

15. Шувар I. Збільшення продуктивності українських ланів. Агробізнес съогодні, 2011. Вип. 14 (213). С. 46-48. 